\title{
Exploring Culture and Peace in the Context of Afghanistan
}

\author{
Javed Noorani \\ Development Practitioner, Kabul, Afghanistan \\ Corresponding author: javed.noorani@gmail.com
}

Received: 10 Jan., 2019
Revised: 15 Apr., 2019

Accepted: 20 May, 2019

\begin{abstract}
Mahatma Gandhi's practice of non-violence sets a unique base for a culture of tolerance, equality, freedom to exercise political, civil and economic rights and allow a natural course for the creation of social capital among people living in society. In the backdrop of conflicts in different parts of the world, it would be worthwhile to explore how the Gandhian principles of nonviolence and nonviolent conflict resolution remain an important compass to work for a culture of peace. This chapter will explore these dimensions in the context of Afghanistan.
\end{abstract}

Keywords: Nonviolence, nonviolent conflict resolution, culture and peace

Discourse on culture in the past two decades or so have been dominated by group of politicians who think some cultures are divisive and dangerous to international "security", without elaborating the "international" in their imagination and defining parameters of "security". The discourse is certainly dominated. This discourse has fragmented the world into pieces and this is further motored by self-centered and suicidal political leadership in quest for reaching power through constructing a scenario of fear ${ }^{1}$. People are mobilized by creating the "other" from within a collectivity formerly living in harmony. The "other" is projected as an enemy and demonized recurrently to recurrently extend vote bank and chances to reach position of power. Peace theorists and practitioners have been in disarray to continuously meet failure and this is largely due to the market factors within their realm of operations. Humans can heal their despair if they step out of the box and seek solutions to conflict and disputes away from dictates from politicians who denounce or brand the role of cultures as subversive. Gandhi's relevance as a practitioner of peace comes under limelight with new rigor.

\section{Modernity and the rise of exclusive nationalism}

Gandhi's practice of non-violence sets a unique base for a culture of tolerance, equality, freedom to exercise political, civil and economic rights and allow a natural course for the creation of social capital among people living in society. A humanist by nature and practice, Gandhi walked his philosophy to reach out to all Indian during their national struggle for independence. Gandhi practiced what he preached, and people saw that as selfless effort for a collective endeavor ${ }^{2}$. He was masterly aware of the cultural differences in India and knew religious diversity would be a major hurdle to bringing everyone to a platform and strive for a common future of liberty and self-rule ${ }^{3}$. Gandhi's vision of peace was for all and inclusion of all was important element of the freedom struggle. Gandhi's recognition of cultural collectivity and leadership in combination won India its independence ${ }^{4}$. Gandhi' philosophy also defined the character of the state and democracy in the country which is why the state has remained so 
resilient to unconstitutional interventions. Gandhi integrated a culture of tolerance and co-existence in the Indian culture based on his love of the freedom of the country and not hatred of the British occupying army.

Many countries across the world are undergoing rapid fragmentation largely driven by identities. The narrative can be couched in the Afghan social fragmentation. Afghanistan has been known as the land of Sufis which created a pluralist's space for all human beings irrespective of color, creed, religion or language, today is deeply divided on ethnic line which erodes social capital that existed for centuries ${ }^{5}$. Forty years of war has deepened the divide among ethnic groups and there is nothing to stop it.

It is imperative to mention that violent literature has not only made serious intrusion but has entrenched into the Afghan families, society and markets. In contemporary Afghan society political figures and networks are mostly engaged in "fear politic" to mobilize support and resources on ethnic line in their quest to reach positions of power. It has the resemblance of blinding majority of people into a homogeneous group by very few and blackmail them to fall in line. Ethnic leaders highlight minor identities as major and create the "others" and persuasively demonize them ${ }^{6}$. Some of them use a historical narrative of atrocities perpetrated by dictators to seek larger share of resources. This is a common approach among all major ethnic groups in the country. It has effectively broken major communication channels among different groups and thus the space for cultural exchanges has been eroded completely. Geographies have been curved out on ethnic lines and life for even the best is ghettoed. For instance, hard core convicted criminals are protected based on ethnic lines. In ghettoes, truth dies, and intellectuals silenced or assimilated. This is happening in sharp contrast to the vibrant past of the Afghan culture. The ethnic groups in country share a lot in common yet the elite in each ethnic community continue to divide, widen gaps among people to define homogeneous cultural and linguistic communities in pursuit of their personal or network goals. This has had major impact on the conflict. For example, communities in south and east of the Afghanistan are caught in an intense conflict between the government forces and insurgents. The government forces carry out raids on insurgents who often live with civilians and this often leads to massive civilian casualties. Insurgents often carry out attack on security forces in urban centers and these attacks have killed tens of thousands of innocent people in the past decade. Elites in ethnic communities in best case scenario simply remain silent and in worst case celebrate this tragic happening to one community. These elites have successfully ethnicized every space and many poets who were household names in Afghanistan. For example, cricket which in the recent past has become a fever among the youth in the country and has lured many to pursue career in it after the rise of Rashed Khan, is termed by ethnic leader as a sport of an ethnic group, thus denying or deriving youth of their own community from the fun and beauty of the sport. Rumi a universal Sufi poet is subjected to derogatory remarks to hurt the sentiments of another ethnic group because like the case of cricket, he is associated with an ethnic group. It has sadly gone to ethincizing tea and some other food items and they are not eaten simply because it is associated with an ethnic group ${ }^{7}$.

Fear is manufactured at large scale and new communities are constructed by politicians to define and project oneself as a survival pole. They have successfully created demand among their ethnic communities through their narrative. The entrenchment of corrupt political elites leads to structural flaws in state character which will at some point need correction. The leadership has often taken advantage of this and attempted selfenrichment in the name of their communities. The justification often is to claim a fair share of the resources and positions in the state in the name of their respective ethnic groups which they end up distributing among a handful of close friends and associates. Leaders have largely played dividersin-chief rather than like Gandhi stepping over their interest to bring together people from all groups to one platform to work for a collective cause. The sense empathy among people is destroyed in 
the case of Afghanistan. However, at the highest level these ethnic entrepreneurs from all groups are part of an economic club where they wine and dine together because their interest binds them into sharing the loot. In the turmoiled binary of Afghanistan polity one can be witness to a "befooled majority" nursing their never healing wounds and affluent elite minority that is adding to their riches in chaos. Similarly, there are sectarian groups that use religion to justify violence against other groups. Sectarian groups have been arming themselves due to fear of attacks from the other groups. It is a puzzle to see people kill each other in quest for Heaven. It is equally mysterious that the religious figures in the country have reduced human relationship to their Lord, to mere transections, meaning that human beings will do something in return for something. What is missing is love of human being and love of Lord without any string attached.

Movlene Rumi's saying that has become relevant is "there are as many ways to the Lord as there are human beings", effectively liberate human faith from the blackmail of the clergy and conveys to human beings that their relationship with their Lord is based on love. The Lord rejoices when one Human being loves another human being. This lovebased culture in Afghanistan has been commuted for a culture of violence. What is practiced in Afghanistan is exclusive ethnic nationalism built to belittle and demonize the "others" and pursue a path of hate to power and authority. The vicious cycle has only generated more hatred and has scared people to play of leadership role to disrupt this cycle. Pursuit of power has often resulted into violence as well.

Most cultures have many strong points and some weak. Cultures replace weak points continuously in response to changing environment and in contact with other cultures. Cultures have enriched through interactions with other cultures. Cultures demonstrate to others its values colors and fascination. Every culture has processes and protocols for life, co-existence, peace and conflict resolutions. Cultural exchange offers limitless opportunities for human beings across the spectrum to learn more about others and above all become better human beings.

Cultural exchange provides space for flow of thoughts and literature about a different collectivity which may spin off several conversations post interactions. Exchanges help flow and fluidity. For example, interaction in a peaceful and common space among people of different culture will certainly evoke human feelings of understanding and empathy. In a cultural interface, new ideas may be exchanged, and they may become household conversation among family members for further discussion which will eventually resonate in new spaces. This is recipe for "social capital" underpinned by informed minds and empathy. Human beings will change into recognizing cultural diversity and engage in spaces for collective good and secure parameters for collectivity stability and yet practice their relations with their own Gods in their private spaces without any encroachment. One of the old saying with perpetual relevance from the Indian context is the saying of Khwaja Ghareeb Nawaz who said" Cheshtyo Holy kilo" meaning Cheshtyee play holy. Khawaj Ghareeb Nawaz of Ajmer, a Muslim Sufi, tells his disciples to play the festival of color about 800 years ago. It speaks volumes about love for the fellow human beings living there. He encouraged sharing space, values and happiness to add to festivity. Gandhi practiced his own faith while he deeply respected other faiths and engaged with them-certainly a true personal and cultural enrichment as a clear outcome of engagement with diversity.

\section{Cultural as peace productive}

Exchanges in domain of culture among people can facilitate streams of thoughts for a shared future based on empathy and collective interest. Knowing someone, or his/her stories or a situation better will avoid ill-informed judgment on part of many human beings. Gandhi promoted interaction and offered space for non-violent thinking and dialogue among people ${ }^{8}$. Spaces need to be increased for people to people contact and exchanges to share challenges, understand each other and collectively work for 
finding solutions to a problem. Such engagement will not only stop the development of malicious stories about other citizens, but force politicians change course of action to seek votes based on better programs and depart from politics of hate'. Gandhi with patience inspired others for peace because he loved independence and not because he hated the British Army. Gandhi's thoughts and philosophy have continued to remain relevant as solution to contemporary conflicts.

\section{REFERENCES}

http://www.gandhi-manibhavan.org/activities/essay_ cultureofpeace.htm http://www.gandhiashramsevagram.org/gandhi-articles/ gandhi-philosophy-of-nonviolence.php

https://journals.openedition.org/poldev/2326\#tocto1n2

https://themysticcall.wordpress.com/the-great-sufis-of-theland-of-afghanistan/

https://www.gandhiashramsevagram.org/gandhi-articles/ gandhi-vision-of-peace.php

https://www.gandhiashramsevagram.org/gandhi-articles/ gandhi-vision-of-peace.php

https://www.mei.edu/sites/default/files/publications/2009.12. Afghanistan\%201979-2009.pdf

https://www.thesunmagazine.org/issues/90/gandhis-wayto-peace 